\title{
Analisis Ketersediaan dan Kebutuhan Beras di Indonesia Tahun 2018
}

\author{
Armandha Redo Pratama, Sudrajat, Rika Harini
}

Masuk: 09082019 / Diterima: 20092019 / Dipublikasi: 31122019

(c) 2019 Fakultas Hukum dan IImu Sosial UNDIKSHA dan IGI

\begin{abstract}
Based on the publication of the World Bank in 2018, Indonesia is currently ranked 4th as the country with the most significant number of population in the world. The consumption of rice is also increasing because of the growth of the people. This study aims to analyze the availability and needs of rice in Indonesia. The method used in this research is literature study and secondary data analysis. The result of the study shows that geographical conditions in Indonesia, which are most suitable as agricultural land, make the availability of rice in Indonesia quite large. This is evidenced by the percentage of rice surplus areas in Indonesia higher than the rice deficit area, which is $52,94 \%$ : 47,06\%. Most of the provinces in Indonesia with a rice deficit classification are in East Indonesia, such as Papua, Maluku, NTT dan NTB. In contrast, the areas with the dominant rice surplus classification are in Java, Sumatera, and Sulawesi. So, in general, in 2018, most provinces in Indonesia are rice surplus regions, and rice centers are in Java, Sumatera, and Sulawesi.
\end{abstract}

Key words: Availability; Need; Rice; Surplus; Deficit

Abstrak Berdasarkan publikasi World Bank pada tahun 2018, Indonesia menduduki peringkat ke-4 sebagai negara dengan jumlah penduduk paling besar di dunia, hal ini mengakibatkan konsumsi beras di Indonesia juga besar. Tujuan penelitian ini ialah untuk menganalisis ketersediaan dan kebutuhan berasdi Indonesia. Metode yang digunakan dalam penelitian ini ialah metode studi literatur dan analisis data sekunder. Hasil analisis dalam penelitian ini ialah Kondisi geografis di Indonesia yang sebagian besar cocok sebagai lahan sawah menyebabkan ketersediaan beras di Indonesia cukup besar. hal ini dibuktikan dengan persentase wilayah surplus beras di Indonesia lebih besar dibandingkan dengan wilayah defisit berasnya, yaitu sebesar 52,94\%: 47,06 \%. Sebagian besar Provinsi dengan klasifikasi defisit beras berada di Indonesia bagian timur, seperti Provinsi Papua, Maluku, NTT dan NTB, sedangkan provinsi dengan klasifikasi surplus beras dominan berada di Pulau Jawa, Pulau Sumatera dan Pulau Sulawesi. Jadi secara umum pada tahun 2018 sebagian besar provinsi di Indonesia merupakan wilayah surplus beras dengan sentra beras berada di Pulau Jawa, Pulau Sumatera dan Pulau Sulawesi.

Kata kunci : Ketersediaan; Kebutuhan; Beras; Surplus; Defisit

\section{Pendahuluan}

Indonesia merupakan negara yang memiliki jumlah penduduk yang cukup besar. Menurut publikasi World Bank pada tahun 2018, Indonesia menduduki peringkat ke-4 sebagai negara dengan jumlah paling besar di dunia setelah China. India dan Amerika Serikat, dengan jumlah penduduk sebanyak 263.991.379 jiwa.

Armandha Redo Pratama, Sudrajat, Rika HariniFakultas Geografi, Universitas Gadjah Mada

armandharedo46@gmail.com
Selain jumlah penduduk yang besar, Indonesia juga dianugerahi oleh potensi sumberdaya wilayah yang cukup besar dengan tingkat keragaman sumberdaya wilayah yang sangat besar, hal ini dikarenakan kondisi geografis Indonesia yang sangat mendukung. Salah satu sumberdaya wilayah tersebut terdapat pada sektor pangan berupa tanaman padi yang dapat tumbuh di sebagian besar wilayah Indonesia.

Berdasarkan

rencana pembangunan jangka menengah nasional (RPJMN) tahun 2015-2020, disebutkan 
bahwa terdapat tiga masalah pokok bangsa, diantaranya yaitu ancaman terhadap wibawa negara, melemahnya sendi-sendi perekonomian nasional, serta merebaknya intoleransi dan krisis kepribadian bangsa. Pada poin melemahnya sendi-sendi perekonomian nasional, di dalam RPJMN Indonesia juga dijelaskan salah satu masalah yang dihadapi ialah ketergantungan dalam hal pangan.

FAO pada tahun 2006 menyebutkan bahwa dimensi ketahanan pangan terdiri atas empat aspek, yaitu food availability, food access, utilization dan stability. Keempat indikator tersebut menggambarkan beberapa aspek yang terdiri atas penawaran, permintaan, distribusi, pemanfaatan serta usaha menjaga stabilitas harga dari komoditas pangan. Berdasarkan pengertian tersebut, maka dapat disimpulkan bahwa ketahanan pangan meliputi beberapa aspek, yaitu: (1) kecukupan ketersediaan pangan, (2) keterjangkauan akses terhadap pangan, (3) pemanfaatan pangan dan (4) stabilitas harga pangan.

Permasalahan ketahanan pangan menjadi isu starategis sampai saat ini, salah satu faktor penyebab masalah ketahanan pangan adalah alih fungsi lahan. Seperti yang dikemukakan oleh Suratha (2014) bahwa alih fungsi lahan merupakan konsekuensi dari akibat meningkatnya aktivitas dan jumlah penduduk serta pembangunan yang lainnya. Alih fungsi lahan pada kenyataannya membawa banyak masalah karena terjadi di atas lahan pertanian yang masih produktif.

Alih fungsi lahan juga memberikan dampak pada aspek sosial ekonomi karena berpengaruh pada pendapatan dan kesempatan kerja yaitu masyarakat melakukan peralihan mata pencaharian atau yang disebut sebagai transformasi sosial ekonomi (Haris, Subagio, Santoso, \& Wahyuningtyas, 2018).
Arah perubahan pemanfaatan lahan yang dilakukan petani dapat dilihat dari dua bentuk perubahan yaitu perubahan lahan secara vertkal dan perubahan lahan secara horisontal. Perubahan pemanfaatan lahan sawah secara vertikal merupakan perubahan bentuk intensitas dari pemanfaatan lahan sawah karena adanya perubahan pola tanam dari berbagai jenis komoditi yang diusahakan, frekuensi penanaman dan diversifikasi tanaman. Perubahan pemanfaatan lahan sawah secara horisontal pada dasarnya diarahkan untuk merubah lahan sawah menjadi lahan non pertanian (Atmaja, 2015).

Frazelle (2002) menyebutkan bahwa dalam pelaksanaan aktivitas logistik, transportasi merupakan aspek yang meghabiskan dana paling besar, dan biasanya menghabiskan 46,5\% - 58,6\% dari keseluruhan biaya logistik. Pada dasarnya biaya transportasi ini dapat ditekan dengan mengatur sistem transportasi yang ideal.

Laksmiari (2017) menyebutkan bahwa provinsi di Indonesia masih melakukan kegiatan impor beras yang cukup besar hingga tahun 2015, padahal ketersediaan beras di Indonesia seharusnya dapat memenuhi kebutuhan beras jika distribusinya seimbang. Hal ini memicu permasalahan lain dalam hal ketahanan beras di Indonesia, seperti tidak meratanya persebaran beras. untuk itu diperlukan analisis ketersediaan dan kebutuhan beras pada masing-masing provinsi di Indonesia. Hasil analisis ini dapat menjadi dasar dalam penentuan jalur distribusi beras yang optimal pada tahapan selanjutnya.

Informasi ketersediaan dan kebutuhan beras sudah sering kita dapatkan dari berbagai sumber, namun analisis yang berfokus pada analisis secara ilmiah berdasarkan hasil riset dari data statistik pertaian masih sangat jarang dilakukan sehingga penelitian terhadap 
ketersediaan dan kebutuhan beras berbasis analisa data statistik menjadi sangat penting dilakukan dalam perkembangan saat ini.

Berdasarkan uraian tersebut maka perlu adanya analisis yang dilakukan secara komprehensif. Penelitian ini bermaksud untuk melihat bagaimana ketersediaan dan kebutuhan beras di Indonesia pada tahun 2018.

\section{Metode}

Penelitian ini merupakan penelitian kuantitatif dengan menyajikan pembahasan berdasarkan data-data yang disediakan oleh instansi yang berwenang, sehingga teknik analisis yang digunakan ialah analsisis deskriptif kuantitatif menggunakan data sekunder. Pengumpulan data sekunder dilakukan dengan menginventarisasi dokumendokumen dari Badan Pusat Statistik, yaitu Analisis Bahan Pokok (BPS, 2018).

\section{Ketersediaan Beras}

untuk indicator ketersediaan beras, penulis menggunakan persamaan yang terlampir pada Peraturan Menteri Pertanian Nomor 43/Permentan/OT.140/\&/2010 tentang Pedoman Sistem Kewaspadaan Pangan dan Gizi. Persamaan yang digunakan ialah sebagai berikut:

Perhitungan susut gabah:

$\operatorname{Benih}(s)=P \times 0,9 \%$

Pakan ternak $(f)=P \times 0,44 \%$.

Tercecer $(w)=P \times 5,4 \%$

Perhitungan susut gabah bertujuan untuk mengkonversi perubahan padi (gabah) menjadi beras, konversi ini berdasarkan nilai susut akibat digunakan sebagai pakan ternak, padi yang tercecer saat proses penggilingan, dan penggunaan sebagian padi sebagai benih untuk penanaman selanjutnya.
Selanjutnya dilakukan Perhitungan produksi netto beras (Rnet) dengan menggunakan persamaan beriukut:

$$
\begin{aligned}
& \text { Pnet }=P-(s+f+w) \\
& \text { Rnet }=c \times \text { Pnet } \\
& \text { P : Produksi Padi } \\
& \text { Pnett : Produksi netto padi }(\mathrm{kg}) \\
& \text { Rnett : Produksi netto beras }(\mathrm{kg}) \\
& \text { C : : 0,632 }(\mathrm{kg})
\end{aligned}
$$

\section{Kebutuhan Beras}

Analisis kebutuhan beras dilakukan dengan mengolah data statistik berupa jumlah penduduk masing-masing provinsi dan konversi kebutuhan konsumsi beras penduduk di Indonesia per hari per kapita, yaitu sebesar $1,571 \mathrm{~kg} / \mathrm{orang} / \mathrm{minggu}$. Persamaan yang digunakan ialah sebagai berikut:

$K B=J P$ Prov $x C \times M$

Keterangan:

$$
\begin{array}{ll}
\text { KB } & \text { : Kebutuhan beras } \\
\text { JP Prov } & \text { Jumlah penduduk masing- } \\
& \text { masing provinsi } \\
\text { C } & : \text { Rata-rata konsumsi beras } \\
& \text { per orang perminggu } \\
& (1,571 \mathrm{~kg}) \\
\mathrm{M} & : \text { Jumlah Minggu dalam } \\
& \text { setahun }(52,143 \text { minggu })
\end{array}
$$

Hasil dari perhitungan dengan menggunakan persamaan tersebut kemudian dikurangi, sehingga akan dapat diketahui kategori wilayah surplus atau defisit beras.

\section{Hasil dan Pembahasan Ketersediaan Beras}

Analisis ketersediaan beras dilakukan dengan menghitung produksi beras di Indonesia pada tahun 2018. Produksi beras di Indonesia diperoleh dengan memperhatikan nilai susut gabah, sehingga menghasilkan produksi netto beras pada masing-masing provinsi di 
Indonesia. Selain itu faktor ekspor dan impor beras juga menjadi indikator dalam menentukan ketersediaan beras.

Pada Gambar 1 dapat dilihat bahwa Provinsi yang memiliki produksi padi paling tinggi ialah Provinsi Jawa Timur dengan jumlah $10.537 .922 .000 \mathrm{Kg}$ atau 10.537 .922 ton. Jumlah ini menyumbangkan sebesar $18,64 \%$ dari total keseluruhan produksi padi di Indonesia, sedangkan untuk provinsi yang memiliki jumlah produksi padi terendah di Indonesia ialah Provinsi Kepulauan Riau dengan jumlah 833 ton pada tahun 2018. Jumlah ini menyumbangkan hanya sebesar $0,001 \%$ dari total produksi padi secara keseluruhan di Indonesia.

Berdasarkan data tersebut, dapat disimpulkan bahwa Pulau Jawa merupakan sentra produksi padi di Indonesia. Hal ini didukung dengan kondisi geografis di Pulau Jawa yang memungkinkan untuk menanam komoditas padi dengan optimal, selain itu faktor kondisi sosial masyarakat di Pulau Jawa yang lebih menekuni pertanian pada komoditas padi menyebabkan luas laha sawah di Jawa juga lebih luas dibandingkan dengan provinsi lainnya di Indonesia.

Berdasarkan penelitian yang dilakukan oleh Widjono (2006) pada dasarnya merauke memiliki potensi geografis yang sangat besar untuk dijadikan sebagai sentra padi nasional, namun hal yang menjadi faktor penghambat hal ini dapat terwujud ialah padi bukan menjadi komoditas utama di merauke dan kondisi adat serta budaya masyarakat setempat yang tidak umum akan komoditas padi. Penelitian yang dilakukan oleh Suratha (2015) menyebutkan bahwa krisis petani di Indonesia juga dapat mempengaruhi ketahanan pangan. Hal ini disebabkan oleh jumlah petani yang semakin berkurang akan mengurangi penggarap lahan pertanian. Grigg (1974) menyebutkan bahwa di Indonesia pada awalnya ditanam di daerah pegunungan atau lembah-lembah di Pulau Jawa. Untuk daerah pesisir, penanaman padi belum dilakukan karena pada daerah pesisir pada saat itu sering dilanda banjir. Penjelasan tersebut membuktikan bahwa selain faktor geografis yang sesuai, faktor sosial dan budaya masyarakat juga mempengaruhi tinggi atau rendahnya produksi padi lokal di masing-masing Provinsi di Indonesia, salah satunya ialah regenerasi petani.

Data produksi padi yang bersumber dari BPS ini kemudian dilakukan analisis untuk mencari berat netto produksi beras yang ada di Indonesia yang menghasilkan data pada Gambar 2.

\section{Ekspor dan Impor Beras di Indonesia}

Kegiatan ekspor dan impor komoditas perdagangan sudah menjadi hal yang biasa dilakukan oleh setiap negara. Hal ini dikarenakan kondisi geografis masing-masing negara berbedabeda, sehingga tidak semua kebutuhan di suatu negara dapat dipenuhi oleh negara tersebut, sehingga dapat terjadi pertukaran. Untuk mengetahui nilai ekspor dan impor beras di Indonesia dapat dilihat pada tabel 1.

Berdasarkan Tabel 1 dapat disimpulkan bahwa tidak semua provinsi di Indonesia melakukan kegiatan ekspor dan impor beras. Pada tahun 2018 tercatat bahwa total impor beras yang dilakukan ialah sebanyak 2.253.824.465 $\mathrm{Kg}$. Terdapat 15 Pprovinsi yang melakukan kegiatan impor beras, namun Provinsi DKI Jakarta merupakan Provinsi yang paling besar dalam melakukan impor beras, jumlah impor beras yang dilakukan oleh Provinsi DKI Jakarta ialah sebanyak $900.323 .563 \mathrm{Kg}$. 


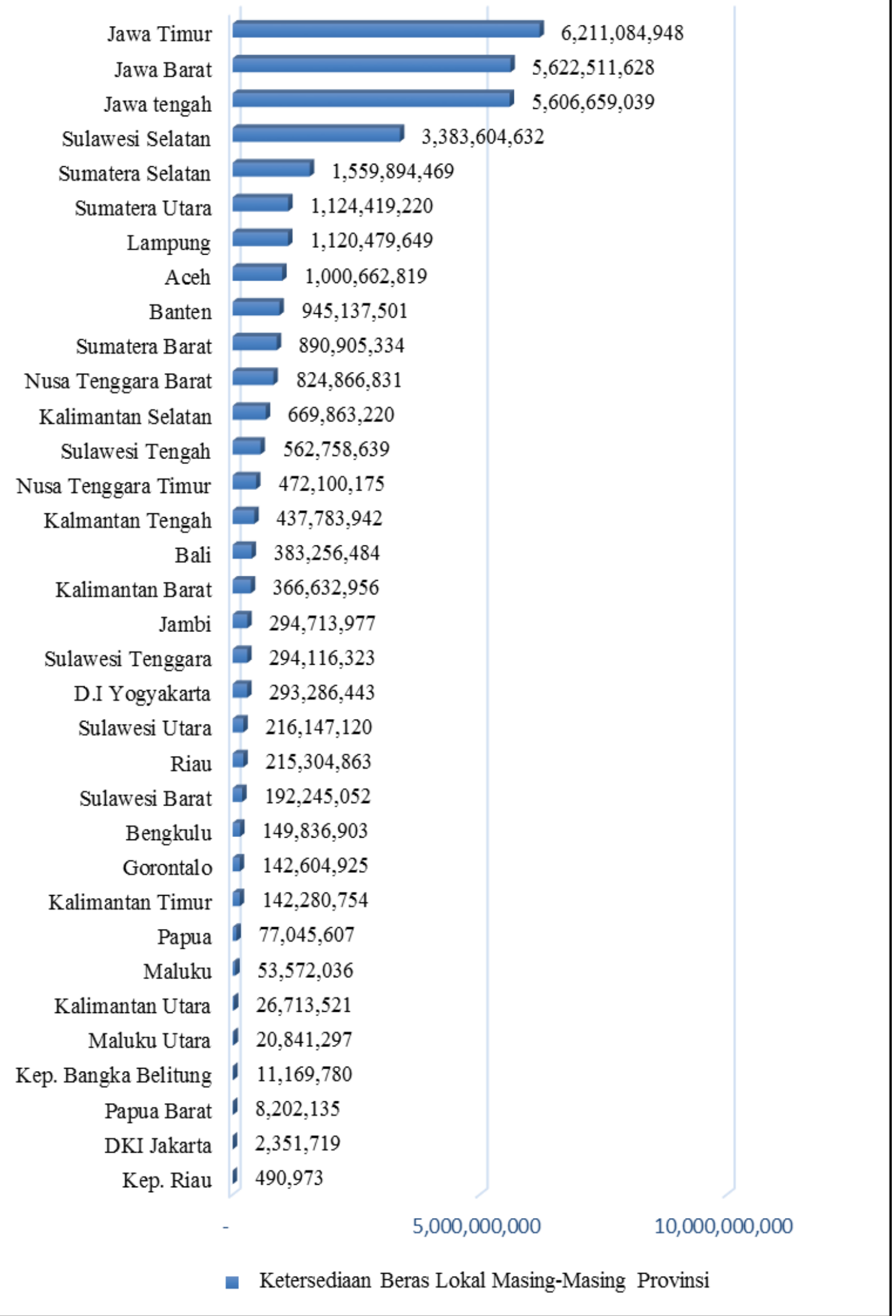

\section{Gambar 1.Ketersediaan Beras dalam Provinsi di Indonesia} (Sumber. BPS, 2018) 
Tabel 1. Jumlah Beras Ekspor-Impor di Indonesia Tahun 2018

\begin{tabular}{clrr}
\hline NO & \multicolumn{1}{c}{ PROVINSI } & IMPOR $(\mathbf{k g})$ & EKSPOR $\mathbf{( k g )}$ \\
\hline 1 & Aceh & 15.000 .000 & - \\
2 & Sumatera Utara & 219.926 .100 & 1.000 .004 \\
3 & Sumatera Barat & 7.500 .000 & - \\
4 & Riau & 10.000 .000 & - \\
5 & Sumatera Selatan & 4.500 .000 & - \\
6 & Lampung & 133.881 .000 & - \\
7 & Kep. Riau & 100.031 & 120 \\
8 & DKI Jakarta & 900.323 .563 & 166.718 \\
9 & Jawa tengah & 901.000 & 35.167 \\
10 & Jawa Timur & 784.042 .471 & 2.010 .702 \\
11 & Banten & 151.000 .000 & - \\
12 & Bali & 4.750 .000 & - \\
13 & Nusa Tenggara Timur & 10.000 .000 & 10 \\
14 & Kalimantan Timur & 300 & - \\
15 & Sulawesi Utara & 11.900 .000 & - \\
& $\quad$ TOTAL & 2.253 .824 .465 & 3.212 .721 \\
\hline
\end{tabular}

Sumber: BPS, 2018

Tabel 2. Ketersediaan Beras Setelah Aktivitas Ekspor-Impor (dalam kg)

\begin{tabular}{clrrrr}
\hline No & Provinsi & $\begin{array}{c}\text { Ketersediaan } \\
\text { Beras Lokal }\end{array}$ & \multicolumn{1}{c}{ Ekspor } & Impor & $\begin{array}{c}\text { Ketersediaan } \\
\text { Beras Total }\end{array}$ \\
\hline 1 & Aceh & 1.000 .662 .819 & 15.000 .000 & 0 & 1.015 .662 .819 \\
2 & Sumatera Utara & 1.124 .419 .220 & 219.926 .100 & 1.000 .004 & 1.343 .345 .316 \\
3 & Sumatera Barat & 890.905 .334 & 7.500 .000 & 0 & 898.405 .334 \\
4 & Riau & 215.304 .863 & 10.000 .000 & 0 & 225.304 .863 \\
5 & Jambi & 294.713 .977 & 0 & 0 & 294.713 .977 \\
6 & Sumsel & 1.559 .894 .469 & 4.500 .000 & 0 & 1.564 .394 .469 \\
7 & Bengkulu & 149.836 .903 & 0 & 0 & 149.836 .903 \\
8 & Lampung & 1.120 .479 .649 & 133.881 .000 & 0 & 1.254 .360 .649 \\
9 & Kep. B. Belitung & 11.169 .780 & 0 & 0 & 11.169 .780 \\
10 & Kep. Riau & 490.973 & 100.031 & 120 & 590.884 \\
11 & DKI Jakarta & 2.351 .719 & 900.323 .563 & 166.718 & 902.508 .564 \\
12 & Jawa Barat & 5.622 .511 .628 & 0 & 0 & 5.622 .511 .628 \\
13 & Jawa tengah & 5.606 .659 .039 & 901.000 & 35.167 & 5.607 .524 .872 \\
14 & D.I Yogyakarta & 293.286 .443 & 0 & 0 & 293.286 .443 \\
15 & Jawa Timur & 6.211 .084 .948 & 784.042 .471 & 2.010 .702 & 6.993 .116 .717 \\
16 & Banten & 945.137 .501 & 51.000 .000 & 0 & 1.096 .137 .501 \\
17 & Bali & 383.256 .484 & $4,750,000$ & 0 & 388.006 .484 \\
18 & NTB & 824.866 .831 & 0 & 0 & 824.866 .831 \\
19 & NTT & 472.100 .175 & 10.000 .000 & 10 & 482.100 .165 \\
20 & Kalbar & 366.632 .956 & 0 & 0 & 366.632 .956 \\
21 & Kalteng & 437.783 .942 & 0 & 0 & 437.783 .942 \\
22 & Kalsel & 669.863 .220 & 0 & 0 & 669.863 .220 \\
23 & Kaltim & 142.280 .754 & 300 & 0 & 142.281 .054 \\
24 & Kalut & 26.713 .521 & 0 & 0 & 26.713 .521 \\
25 & Sulawesi Utara & 216.147 .120 & 11.900 .000 & 0 & 228.047 .120 \\
26 & Sulteng & 562.758 .639 & 0 & 0 & 562.758 .639 \\
27 & Sulsel & 3.383 .604 .632 & 0 & 0 & 3.383 .604 .632 \\
28 & Sul. Tenggara & 294.116 .323 & 0 & 0 & 294.116 .323 \\
29 & Gorontalo & 142.604 .925 & 0 & 0 & 142.604 .925 \\
30 & Sulawesi Barat & 192.245 .052 & 0 & 0 & 192.245 .052 \\
31 & Maluku & 53.572 .036 & 0 & 0 & $53.572,036$ \\
32 & Maluku Utara & 20.841 .297 & 0 & 0 & 20.841 .297 \\
33 & Papua Barat & 8.202 .135 & 0 & 0 & 77.02 .135 \\
\hline 34 & Papua & 77.045 .607 & 0.045 .607 \\
\hline & 33.323.544.916 & $\mathbf{2 . 2 5 3 . 8 2 4 . 4 6 5}$ & $\mathbf{3 . 2 1 2 . 7 2 1} .574 .156 .660$ & \\
\hline & & 54575 & 0 & 0 & \\
\hline
\end{tabular}

Sumber: BPS, 2018 
Provinsi yang melakukan kegiatan impor beras yang terbesar kedua ialah Provinsi Jawa Timur dengan jumlah impor sebanyak $784.042 .471 \mathrm{Kg}$ beras atau $784.042,471$ ton. Hanya terdapat 7 provinsi saja yang melakukan kegiatan ekspor-impor di Indonesia. Provinsiprovinsi tersebut antara lain Provinsi Sumatera Utara, Provinsi Kepulauan Riau, Provinsi DKI Jakarta, Provinsi Jawa Tengah, Provinsi Jawa Timur dan Provinsi Nusa Tenggara Timur. Dapat dilihat bahwa tidak semua provinsi yang melakukan ekspor beras merupakan provinsi dengan jumlah produksi beras lokal yang tinggi. Pada tabel 1 tercatat bahwa Provinsi Kepulauan Riau melakukan ekspor sebanyak $120 \mathrm{Kg}$, padahal seperti yang diketahui bahwa produksi beras lokal di Provinsi Kepulauan Riau merupakan yang terkecil diantara provinsi lainnya di Indonesia.

Hal ini dapat terjadi karena Provinsi Kepulauan Riau memiliki akses yang lebih mudah untuk melakukan kegiatan ekspor impor komoditas, kemudahan tersebut dapat berupa lokasinya yang terdapat dekat pada jalur perdagangan laut internasional, berbatasan dengan negara lainnya dan ketersedian prasarana pendukung kegiatan ekspor impor seperti pelabuhan yang memadai. Hal ini sesuai dengan pernyataan kementrian perdagangan yang menyebutkan bahwa kawasan perbatasan merupakan pendorong ekspor di Indonesia dimana dengan letaknya yang lebih dekat dengan negara tujuan ekspor akan memberikan kemudahan dalam hal akses untuk melakukan ekspor.

Permasalahan impor beras yang lebih tinggi dibandingkan ekspor disebabkan oleh berbagai masalah salah satunya adalah rendahnya tingkat produktivitas padi. Jumlah petani di Indonesia yang semakin berkurang menjadi salah satu penyebabnya. Kondisi ini sejalan dengan penelitian yang dilakukan oleh Suratha, (2015) yang mengemukakan bahwa terjadi penurunan yang signifikan terhadap jumlah petani di Indonesia. Selama periode 10 tahun yaitu dari tahun 2003 sampai 2013, Indonesia mengalami penurunan jumlah petani sangat drastic yakni dari 31,23 juta menjadi 26,14 juta orang. Berkurangnya jumlah peta secara langsung akan berpengaruh pada tingkat produktivitas beras.

\section{Ketersediaan Beras di Indonesia Setelah Aktifitas Ekspor-Impor}

Ketersediaan beras dalam pembahasan ini merupakan ketersediaan beras lokal yang telah disesuaikan dengan kondisi ekspor dan impor beras yang dilakukan pada masing-masing provinsi. Pembahasan sebelumnya telah dijelaskan terkait ketersediaan beras pada masingmasing provinsi, selain ketersediaan beras lokal, juga terdapat kegiatan ekspor dan impor yang dapat merubah jumlah ketersediaan beras pada masing-masing provinsi. Jumlah ketersediaan beras keseluruhan di Indonesia dapat dilihat pada Gambar 2

\section{Berdasarkan Gambar 2 dapat} disimpulkan bahwa terdapat beberapa provinsi yang memiliki jumlah ketersediaan total beras yang lebih tinggi dibandingkan dengan jumlah ketersediaan beras yang dihasilkan di daerahnya. Provinsi DKI Jakarta memiliki perbedaan jumlah yang signifikan, dimana pada data produksi beras lokal Provinsi DKI Jakarta hanya mampu menghasilkan sebanyak $2.351 .719 \mathrm{~kg}$ beras. Jumlah ini merupakan jumlah terkecil kedua setelah Provinsi Kepulauan Riau. Hal berbeda ditunjukan ketika jumlah produksi beras lokal yang dihasilkan oleh Provinsi DKI Jakarta diakumulasikan dengan jumlah ekspor dan impor beras yang dilakukan. Jumlah ketersediaan beras yang terdapat di Provinsi DKI Jakarta menjadi sebanyak $902.508 .564 \mathrm{~kg}$ atau menempati peringkat 10 terbesar dalam ketersediaan beras total di Indonesia. 


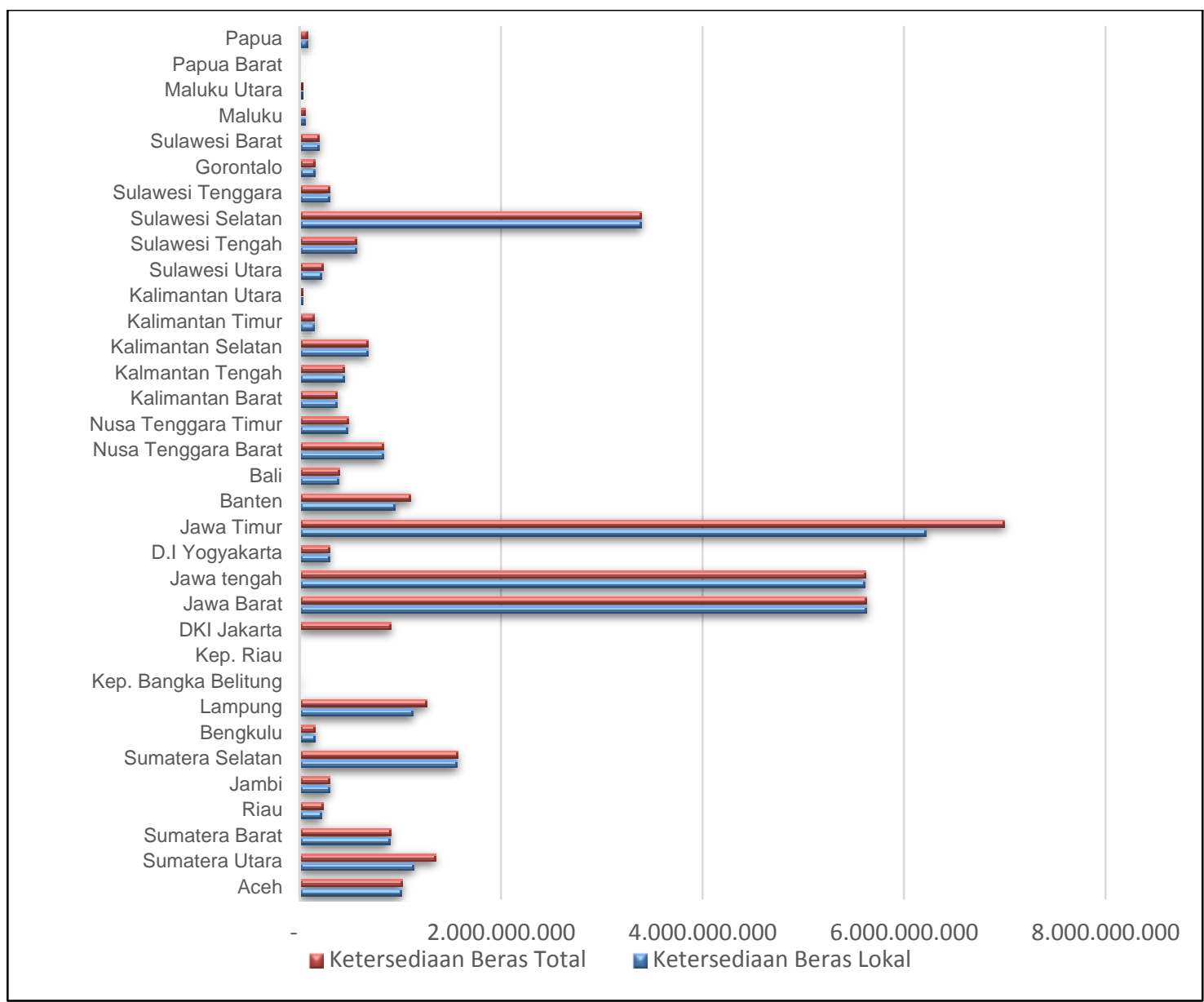

Gambar 2. Ketersediaan Beras Setelah Kegiatan Ekspor-Impor

(Sumber. BPS, 2018)

Perubahan jumlah ini merupakan akibat dari kegiatan ekspor impor yang dilakukan. Hal ini menunjukan bahwa ketersediaan beras yang menjadi faktor dalam mendukung ketahanan beras, semata-mata tidak hanya melibatkan produksi beras lokal saja, tetapi juga kegiatan perdagangan beras baik nasional maupun internasional, sehingga kesiapan dan kemampuan masing-masing provinsi di Indonesia dalam mengoptimalkan potensi wilayahnya dalam hal melakukan perdagangan beras baik seacara nasional maupun internasional menjadi faktor pentingng yang dapat mendorong ketersediaan beras untuk memenuhi kebutuhan pangan di Indonesia.

\section{Kebutuhan Beras}

Jumlah penduduk Indonesia yang besar mengakibatkan kebutuhan beras di
Indonesia juga sangat besar, hal ini dapat dilihat pada data Global Indonesia Investment tahun 2017 yang menyebutkan bahwa Indonesia merupakan negara konsumen beras terbesar di dunia. Untuk mengetahui tingkat kebutuhan beras di Indonesia, diperlukan perhitungan jumlah penduduk dan konversi kebutuhan beras perkapita.

Berdasarkan data BPS (2018) diperoleh data bahwa secara keseluruhan jumlah penduduk di Indonesia pada tahun 2010 tercatat sejumlah 237.899.060 jiwa. Jumlah ini semakin bertambah pada tiap tahunnya, tercatat bahwa pada tahun 2017 jumlah penduduk di Indonesia meningkat menjadi 261.890 .900 jiwa. Berdasarkan data tersebut kemudian dapat dianalisis proyeksi jumlah penduduk pada tahun 2018 dengan angka pertumbuhan penduduk yang digunakan 
berdasarkan data yang dirilis oleh badan pusat statistik, sehingga diperoleh jumlah penduduk di Indonesia pada tahun 2018 ialah sebesar 280.220.107 jiwa. Untuk mengetahui lebih detail terkait jumlah penduduk pada tahun 2018 dapat dilihat pada Tabel 3. Jumlah penduduk yang besar akan dapat mempengaruhi kebutuhan beras di suatu wilayah. Informasi terkait kebutuhan beras masingmasing provinsi di Indonesia dapat dilihat pada Tabel 3 dan Gambar 3. Berdasarkan Tabel 3 dapat disimpulkan bahwa Provinsi Jawa Barat memiliki kebutuhan beras paling besar disbanding dengan provinsi lainnya. Jumlah kebutuhan beras di Provinsi Jawa Barat ialah sebesar
4.439.830.328,81 kg. Provinsi kedua yang memiliki jumlah kebutuhan beras terbesar ialah Provinsi Jawa Timur, yaitu sebanyak $3.387 .290 .252,53 \mathrm{~kg}$.

Hasil penelitian Suratha (2014) menyebutkan bahwa jumlah penduduk yang semakin meningkat ternyata tidak hanya mempengaruhi jumlah kebutuhan pangan, namun juga dapat mempengaruhi ketersediaan, dimana jumlah penduduk yang semakin bertambah akan meningkatkan kebutuhan lahan pemukiman, hal ini dapat menyebabkan peningkatan alih fungsi lahan pertanian yang pada akhirnya dapat mengurangi luas lahan dan produksi komoditas pangan.

Tabel 3. Kebutuhan Beras Tahun 2018

\begin{tabular}{|c|c|c|c|c|}
\hline No & Provinsi & $\begin{array}{c}\text { Proyeksi Penduduk } \\
\text { (jiwa) }\end{array}$ & $\begin{array}{c}\text { Kebutuhan Beras } \\
\text { Per Kapita Pertahun }\end{array}$ & $\begin{array}{c}\text { Kebutuhan Beras } \\
(\mathbf{k g})\end{array}$ \\
\hline 1 & Aceh & 6.070 .795 & 52.143 & $497.299 .218,41$ \\
\hline 2 & Sumatera Utara & 4.671 .703 & 52.143 & $1.295 .481571,48$ \\
\hline 3 & Sumatera Barat & 14.815 .412 & 52.143 & $482.990 .773,85$ \\
\hline 4 & Riau & 2.208 .342 & 52.143 & $668.147 .443,97$ \\
\hline 5 & Jambi & 4.129 .105 & 52.143 & $331.586 .698,76$ \\
\hline 6 & Sumatera Selatan & 11.278 .339 & 52.143 & $759.266 .190,02$ \\
\hline 7 & Bengkulu & 1.327 .421 & 52.143 & $180.900 .021,97$ \\
\hline 8 & Lampung & 4.047 .855 & 52.143 & $745.870 .060,66$ \\
\hline 9 & Kep. Bangka Belitung & 54.199 .362 & 52.143 & $139.286 .385,90$ \\
\hline 10 & Kep. Riau & 36.454 .871 & 52.143 & $216.288 .791,34$ \\
\hline 11 & DKI Jakarta & 41.350 .447 & 52.143 & $923.883 .813,83$ \\
\hline 12 & Jawa Barat & 5.604 .782 & 52.143 & $4.439 .830 .328,81$ \\
\hline 13 & Jawa tengah & 4.740 .611 & 52.143 & $2.986 .261 .043,30$ \\
\hline 14 & D.I Yogyakarta & 4.292 .095 & 52.143 & $338.242 .424,30$ \\
\hline 15 & Jawa Timur & 938.567 & 52.143 & $3.387 .290 .252,53$ \\
\hline 16 & Banten & 3.127 .537 & 52.143 & $1.213 .628 .937,28$ \\
\hline 17 & Bali & 1.700 .343 & 52.143 & $382.690 .276,58$ \\
\hline 18 & Nusa Tenggara Barat & 2.640 .352 & 52.143 & $451.560 .185,98$ \\
\hline 19 & Nusa Tenggara Timur & 9.105 .231 & 52.143 & $494.869 .231,69$ \\
\hline 20 & Kalimantan Barat & 2.009 .187 & 52.143 & $459.124 .960,69$ \\
\hline 21 & Kalmantan Tengah & 1.431 .399 & 52.143 & 256.197.339,89 \\
\hline 22 & Kalimantan Selatan & 5.512 .435 & 52.143 & $388.334 .994,79$ \\
\hline 23 & Kalimantan Timur & 6.041 .131 & 52.143 & $351.594 .046,38$ \\
\hline 24 & Kalimantan Utara & 3.804 .749 & 52.143 & $76.884 .266,03$ \\
\hline 25 & Sulawesi Utara & 1.123 .185 & 52.143 & $220.209 .827,21$ \\
\hline 26 & Sulawesi Tengah & 8.156 .430 & 52.143 & $276.978 .675,96$ \\
\hline 27 & Sulawesi Selatan & 1.550 .937 & 52.143 & $775.762 .593,29$ \\
\hline 28 & Sulawesi Tenggara & 9.470 .145 & 52.143 & $252.530 .057,58$ \\
\hline 29 & Gorontalo & 3.381 .225 & 52.143 & $108.737 .917,70$ \\
\hline 30 & Sulawesi Barat & 3.082 .768 & 52.143 & $127047.595,06$ \\
\hline 31 & Maluku & 2.688 .218 & 52.143 & $164.585 .864,39$ \\
\hline 32 & Maluku Utara & 5.896 .124 & 52.143 & $117.255 .414,83$ \\
\hline 33 & Papua Barat & 9.268 .765 & 52.143 & $92.007 .524,49$ \\
\hline \multirow[t]{2}{*}{34} & Papua & 15.814 .630 & 52.143 & $311.672 .282,03$ \\
\hline & Total & 291.934 .498 & & 924.397.020,97 \\
\hline
\end{tabular}




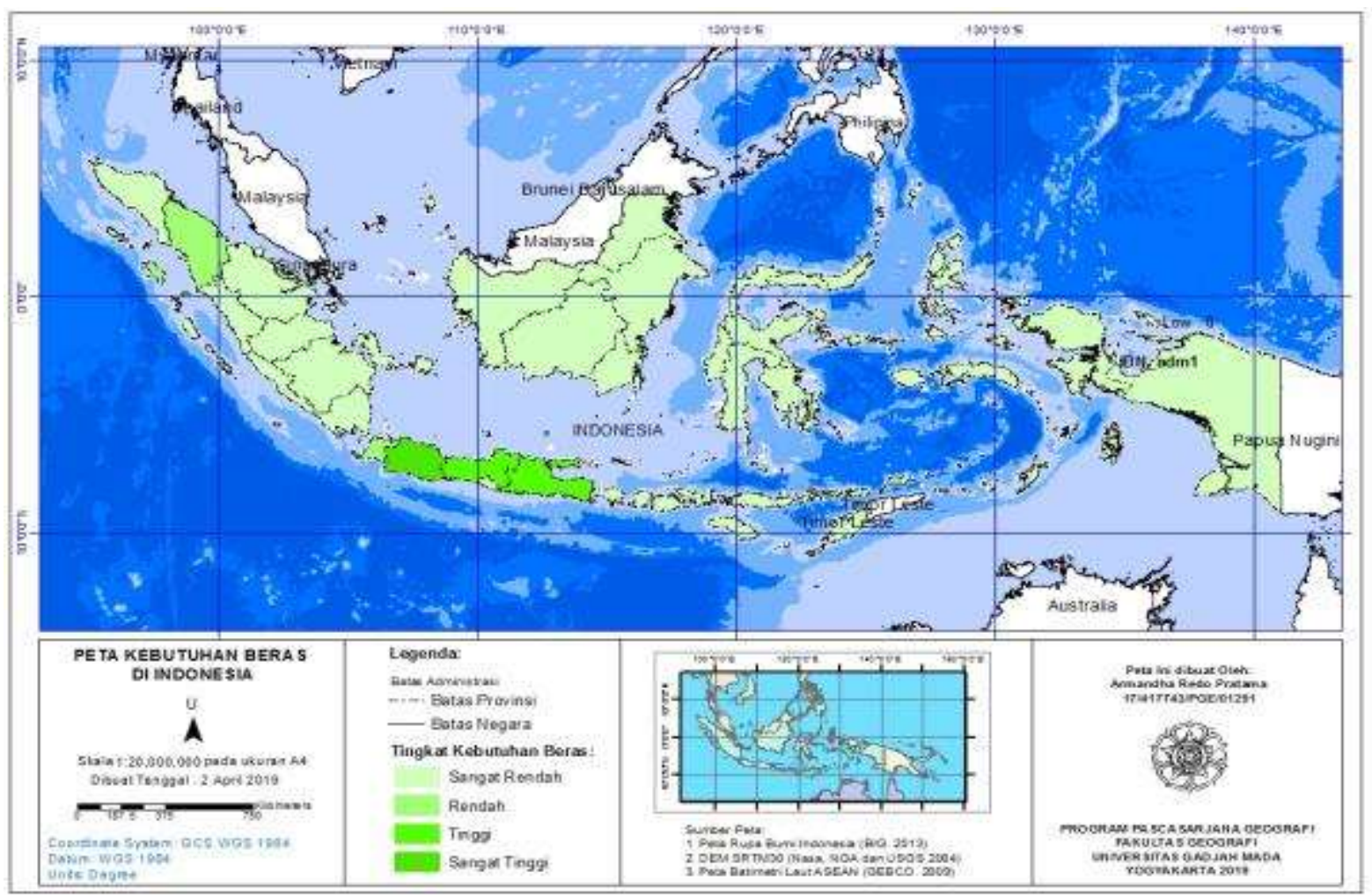

Gambar 3. Peta Tingkat Kebutuhan Beras di Indonesia

(Sumber. BPS, 2018)

Berdasarkan Gambar 3. dapat disimpulkan bahwa sebagian besar provinsi di Indonesia memiliki klasifikasi kebutuhan beras sangat rendah. Provinsi yang memiliki klasifikasi kebutuhan beras sangat tinggi hanya terdapat di Jawa Barat, Untuk provinsi yang memiliki tingkat kebutuhan beras sedang tidak ada, namun untuk tingkat kebutuhan beras rendah hanya di Provinsi Banten, Provinsi DKI Jakarta dan Sumatera Utara.

Kondisi ini menunjukan bahwa tingkat ketimpangan kebutuhan beras antar provinsi di Indonesia cukup besar. Provinsi di Pulau Jawa memiliki kebutuhan kebutuhan beras paling besar, sedangkan selisish jumlah kebutuhan beras pada provinsi lainnya di luar Pulau Jawa tercata cukup besar. Hal ini di dorong oleh kondisi Pulau Jawa yang menjadi berbagai pusat kegiatan maupun pusat pemerintahan di Indonesia, sehingga penduduk Indonesia mayoritas lebih terkonsentrasi di Pulau Jawa yang menyebabkan kebutuhan pangan berasnya juga sangat tinggi.
Konsentrasi penduduk di Pulau Jawa tentu akan menambah kebutuhan akan lahan untuk pemukiman, pendidikan maupun fasilitas umum lainnya. Hal ini tentu akan berpotensi untuk mengurangi lahan pertanian termasuk sawah di Pulau Jawa. Menurut Teori Malthus 1766-1834 terdapat hubungan antara pertumbuhan jumlah penduduk dan ketersediaan pangan. Menurut teori tersebut pertumbuhan akan mengikuti deret ukur, sedangkan ketersediaan pangan akan mengikuti deret hitung. Pada jangka waktu tertentu berdasarkan teori Malthus, maka ketersediaan pangan suatu saat akan sulit mengimbangi kebutuhan pangan akibat pertumbuhan penduduk yang besar. Teori ini tentu memiliki beberapa kelemahan, diantaranya ialah mengabaikan peran teknologi yang mampu meningkatkan produksi pangan dalam hal ini ialah beras secara signifikan dalam waktu yang lebih singkat. 


\section{Keseimbangan Neraca Beras di Indonesia}

Keseimbangan neraca beras diperoleh dengan mengurangi jumlah produksi total beras yang telah digabungkan dengan kegiatan ekspor impor dan jumlah konsumsi beras pada masing-masing provinsi di Indonesia. Berdasarkan Tabel 4 dapat dilihat bahwa Provinsi yang memiliki klasifikasi sebagai wilayah surplus relatif berimbang dengan provinsi yang memiliki klasifikasi defisit beras.

Tabel 4. Analisis Neraca Beras di Indonesia Tahun 2019

\begin{tabular}{|c|c|c|c|c|c|}
\hline No & Provinsi & $\begin{array}{l}\text { Ketersediaan } \\
\text { Beras Total (kg) }\end{array}$ & $\underset{(\mathbf{k g})}{\text { Kebutuhan Beras }}$ & $\begin{array}{c}\text { Selisih } \\
(\mathbf{k g})\end{array}$ & Klasifikasi \\
\hline 1 & Aceh & $1.015 .662 .819,22$ & $468.891 .925,16$ & $518.363 .600,81$ & Surplus \\
\hline 2 & Sumatera Utara & $1.343 .345 .315,92$ & $1.246 .243 .491,85$ & $47.863 .744,44$ & Defisit \\
\hline 3 & Sumatera Barat & $898.405 .334,12$ & $464.771 .106,62$ & $415.414 .560,27$ & Surplus \\
\hline 4 & Riau & $225.304 .863,14$ & $619.171 .909,03$ & $-442.842 .580,83$ & Defisit \\
\hline 5 & Jambi & $294.713 .977,47$ & $314.492 .115,11$ & $-36.872 .721,30$ & Defisit \\
\hline 6 & Sumatera Selatan & $1.564 .394 .469,41$ & $727.388 .347,69$ & $805.128 .279,39$ & Surplus \\
\hline 7 & Bengkulu & $149.836 .902,70$ & $172.131 .418,99$ & $-31.063 .119,27$ & Defisit \\
\hline 8 & Lampung & $1.254 .360 .648,73$ & $720.077 .348,69$ & $508.490 .588,07$ & Surplus \\
\hline 9 & Kep. Bangka Belitung & $11.169 .780,04$ & $130.560 .250,52$ & $-128.116 .605,86$ & Defisit \\
\hline 10 & Kep. Riau & $590.883,87$ & $197.877 .243,66$ & $215.697 .907,47$ & Defisit \\
\hline 11 & DKI Jakarta & $902.508 .563,62$ & $895.382 .093,73$ & $21.375 .250,21$ & Defisit \\
\hline 12 & Jawa Barat & $5.622 .511 .627,86$ & $4.243 .376 .298,68$ & 1.182.681.299 & Surplus \\
\hline 13 & Jawa tengah & 5.607.524.872,39 & 2.917.458.632,27 & 2.621.263.829 & Surplus \\
\hline 14 & D.I Yogyakarta & $293.286 .442,92$ & $326.642 .603,44$ & $-44.955 .981,38$ & Defisit \\
\hline 15 & Jawa Timur & $6.993 .116 .717,11$ & 3.323.077.945,04 & 3.605 .826 .464 & Surplus \\
\hline 16 & Banten & $1.096 .137 .501,36$ & $1.136 .928 .715,55$ & $-117.491 .435,92$ & Defisit \\
\hline 17 & Bali & $388.006 .483,78$ & $369.237 .575,20$ & $5.316 .207,21$ & Surplus \\
\hline 18 & Nusa Tenggara Barat & $824.866 .831,38$ & $433.883 .308,74$ & 373.306 .645 .40 & Surplus \\
\hline 19 & Nusa Tenggara Timur & $482.100 .165,14$ & $470.742 .966,60$ & $-12.769 .066,56$ & Defisit \\
\hline 20 & Kalimantan Barat & $366.632 .955,93$ & $437.644 .575,72$ & $-92.492 .004,76$ & Defisit \\
\hline 21 & Kalmantan Tengah & $437.783 .942,03$ & 239.232.601,04 & $181.586 .602,14$ & Surplus \\
\hline 22 & Kalimantan Selatan & $669.863 .220,24$ & $368.423 .399,20$ & $81.528 .225,45$ & Surplus \\
\hline 23 & Kalimantan Timur & $142.281 .053,67$ & $328.312 .379,29$ & $-209.312 .992,71$ & Defisit \\
\hline 24 & Kalimantan Utara & $26.713 .521,23$ & $68.547 .375,29$ & $-50,170.744,80$ & Defisit \\
\hline 25 & Sulawesi Utara & $228.047 .120,31$ & $213.036 .670,00$ & $7.837 .293,10$ & Defisit \\
\hline 26 & Sulawesi Tengah & $562.758 .638,94$ & $263.708 .534,93$ & $285.779 .962,98$ & Surplus \\
\hline 27 & Sulawesi Selatan & 3.383.604.632,34 & $751.161 .178,54$ & 2.607.842.039 & Surplus \\
\hline 28 & Sulawesi Tenggara & $294.116 .322,62$ & 236.987.542,36 & $41.586 .265,04$ & Surplus \\
\hline 29 & Gorontalo & $142.604 .925,43$ & $103.650 .561,25$ & $33.867 .007,73$ & Surplus \\
\hline 30 & Sulawesi Barat & $192.245 .052,34$ & 119.966.606,98 & $65.197 .457,28$ & Surplus \\
\hline 31 & Maluku & $53.572 .035,65$ & $156.100 .823,11$ & $-111.013 .828,74$ & Defisit \\
\hline 32 & Maluku Utara & $20.841 .297,15$ & $110.070 .999,91$ & $-96.414 .117,67$ & Defisit \\
\hline 33 & Papua Barat & $8.202 .134,93$ & $85.213 .471,14$ & $-83.805 .389,56$ & Defisit \\
\hline 34 & Papua & $77.045 .607,50$ & $294.301 .251,02$ & $-234.626 .674,53$ & Defisit \\
\hline
\end{tabular}


Jumlah Provinsi yang surplus beras tercatat sebanyak 16 provinsi atau sebesar $47,05 \%$, sedangkan provinsi yang defisit beras tercatat sebanyak 18 provinsi atau sebesar $52,9 \%$. Beberapa provinsi yang tergolong klasifikasi surplus beras terbesar di Indonesia ialah Provinsi Jawa Timur, Provinsi Jawa Tengah, Provinsi Sulawesi Selatan dan Provinsi Jawa Barat, sedangkan provinsi yang tergolong klasifikasi defisit beras terbesar di Indonesia ialah Provinsi Riau, Provinsi Papua, Provinsi Kepulauan Riau, Provinsi Kalimantan Timur dan Provinsi Bangka Belitung.
Secara umum, provinsi-provinsi yang termasuk kedalam kategori surplus beras dikarenakan kondisi alam yang mendukung, dimana terdapat gunung api aktif yang mengakibatkan ketersediaan unsur hara yang cukup sebagai media tumbuh padi, selain itu dengan luas pulau yang cukup besar juga mendukung ketersediaan dan akses air untuk irigasi yang cukup dibandingkan dengan Provinsi di pulau-pulau kecil. Informasi wilayah surplus dan defisit beras di Indonesia dapat disajikan dalam bentuk informasi spasial berupa peta yang dapat dilihat pada Gambar 4.

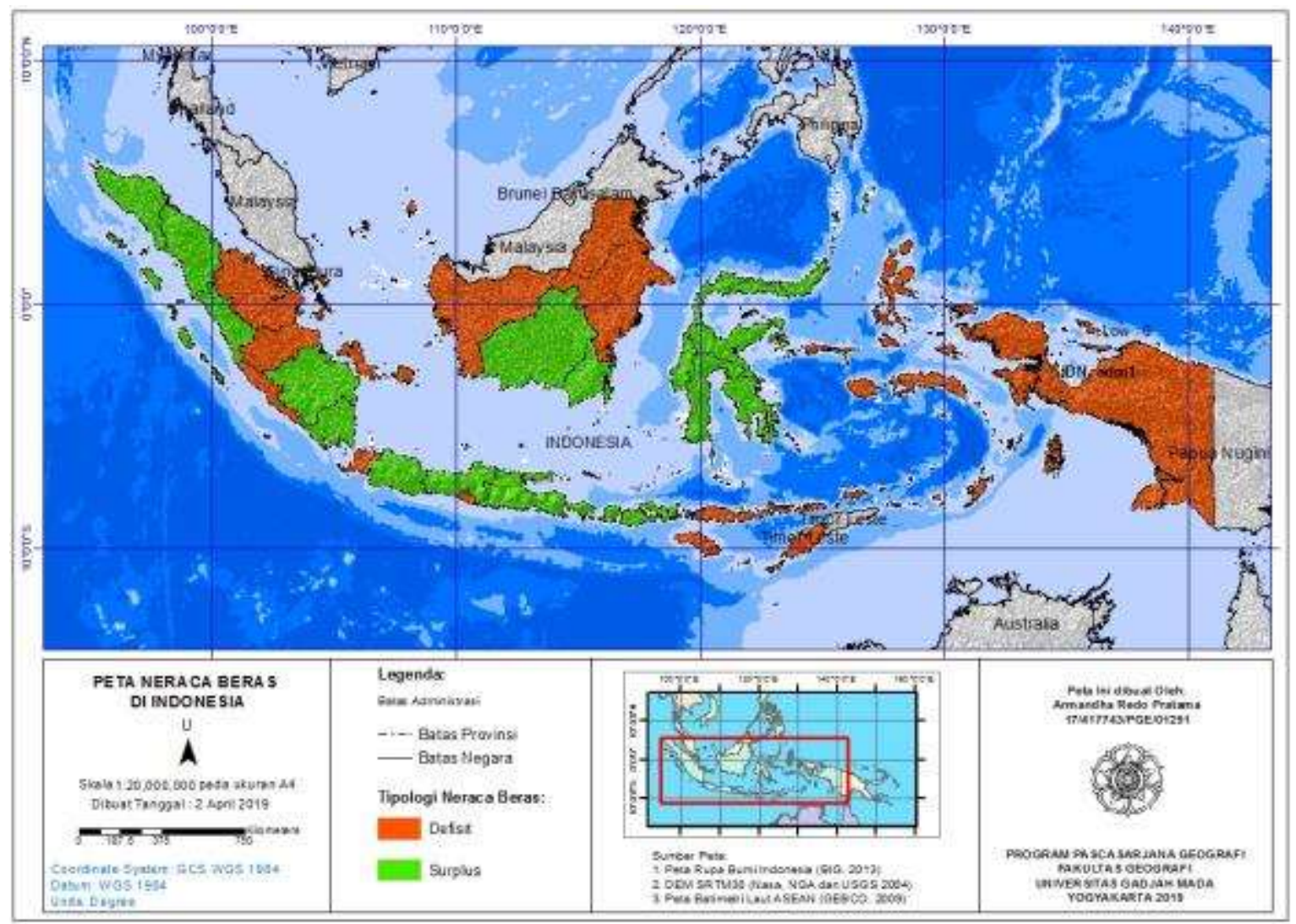

Gambar 4. Peta Neraca Beras di Indonesia Sumber. BPS, 2018

Kondisi menarik terdapat di Pulau Jawa, dimana jumlah penduduk terbesar di Indonesia terkonsentrasi di pulau tersebut. Jumlah penduduk yang besar, biasanya akan memberikan tekanan kepada lingkungan yang mengakibatkan terjadinya alih fungsi lahan. Hal ini dapat dilihat pada Gambar 5 dimana luas lahan sawah di Pulau Jawa relatif menurun dari tahun 2003-2015, namun pada Gambar 6 terlihat bahwa ketersediaan beras di Pulau Jawa justru bertambah. 


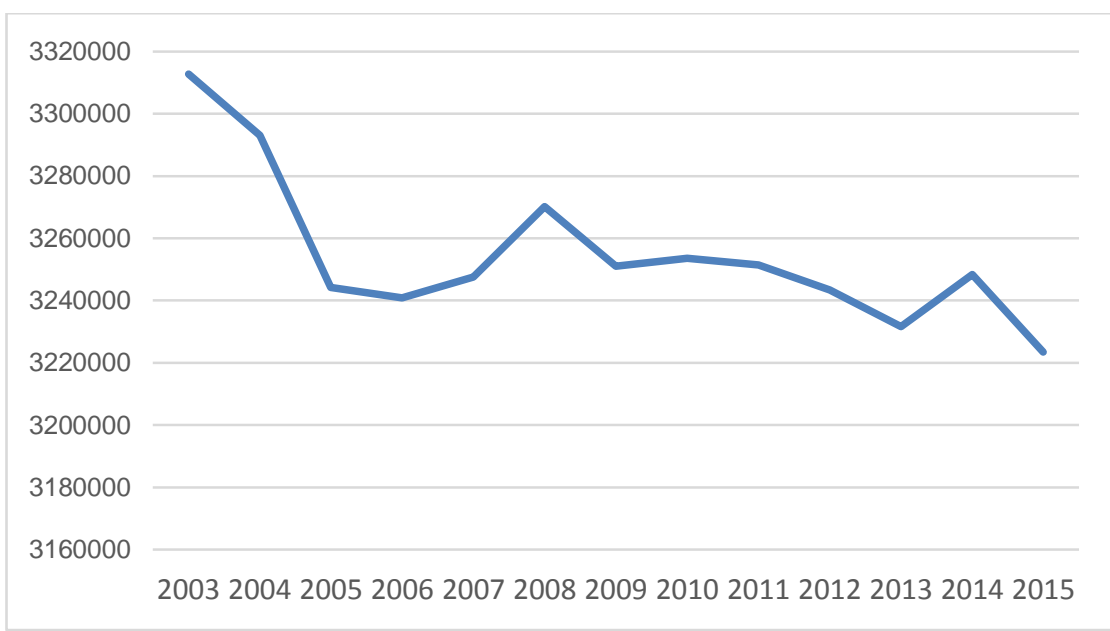

Gambar 5. Luas Lahan Sawah (ha) di Pulau Jawa

(Sumber. BPS, 2018)

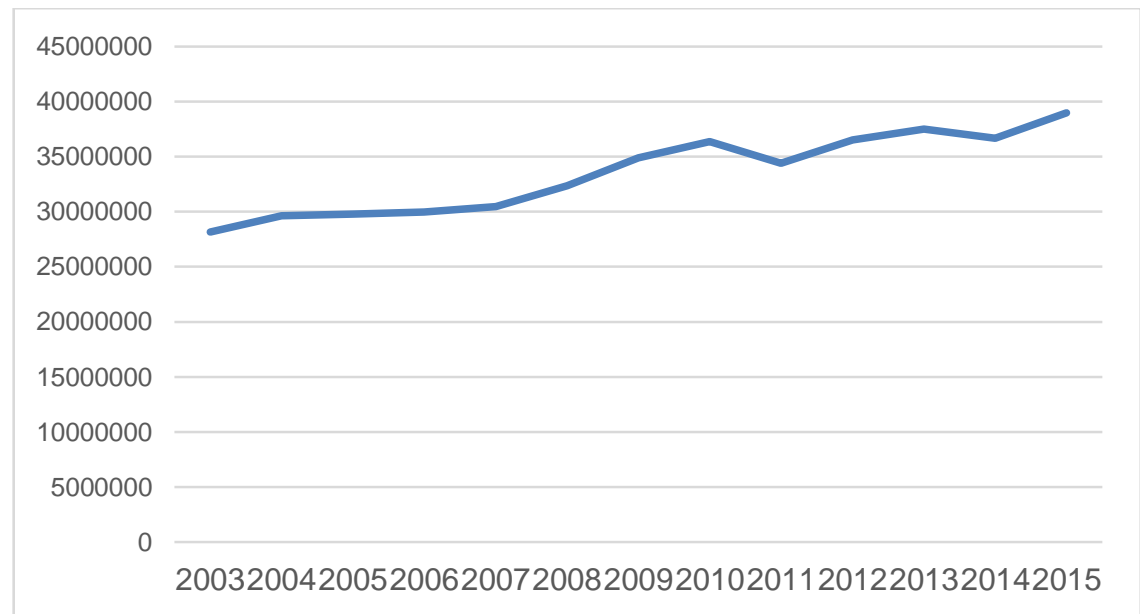

Gambar 6. Ketersediaan Beras (ton) di Pulau Jawa

(Sumber. BPS, 2018)

Berdasarkan uraian tersebut dapat diidentifikasi salah satu kelemahan teori Malthus. Hal ini menunjukan bahwa terdapat faktor lainnya yang dapat mengimbangi pertumbuhan jumlah penduduk, salah satunya adalah teknologi. Robinson (dalam Singgih, 2001) mengungkapkan bahwa tingginya fertilitas pada negara berkembang akan menekan pada tingkat pendapatan pada masa yang akan dating, dimana akan muncul beberapa fenomena seperti increasing returns dari produksi pertanian dan kebutuhan tenaga kerja, perubahan teknologi secara radikal dan jumlah tabungan yang ada pada masyarakat semakin mengecil.

\section{Kesimpulan}

Kondisi geografis di Indonesia yang sebagian besar cocok sebagai lahan sawah menyebabkan ketersediaan beras di Indonesia cukup besar. hal ini dibuktikan dengan persentase wilayah surplus beras di Indonesia lebih besar dibandingkan dengan wilayah defisit berasnya, yaitu sebesar 52,94\% : 47,06 $\%$. Sebagian besar Provinsi dengan klasifikasi defisit beras berada di Indonesia bagian timur, seperti Provinsi Papua, Maluku, NTT dan NTB, sedangkan provinsi dengan klasifikasi surplus beras dominan berada di Pulau Jawa, Pulau Sumatera dan Pulau Sulawesi. Mengetahui wilayah surplus dan wilayah 
defisit beras akan mengetahi bagaimana posisi ketersediaan beras, sehingga pada tahap selalnjutnya dapat dilakukan pemodelan distribusi beras yang ideal dengan biaya optimum agar dapat menyeimbangkan keseimbangan pasokan beras pada setiap provinsi.

Hasil analisa data ketersediaan dan kebutuhan terhadap beras dapat digunakan untuk menentukan kebijakan dan menjadi dasar dalam penentuan jalur distribusi beras yang optimal pada tahapan selanjutnya.

\section{Daftar Pustaka}

Atmaja, D. M. (2015). Dampak Strategi Petani Dalam Merubah Arah Pemanfaatan Lahan Sawah Terhadap Kenyamanan Hidup Di Kota Denpasar. Media Komunikasi Geografi, 16(1), 01-13.

BPS. (2018). Analisis Bahan Pokok Indonesia. Jakarta: Badan Pusat Statistik.

Frazelle, E. (2002). Supply Chain Strategy. New York: McGraw-Hill.

Grigg, D. B. (1974). Agricultural Population and Economic Development. Journal of Tijdshrift Voor Economische En Sociale Geografie, 65(6), 67-74.

Haris, A., Subagio, L. B., Santoso, F., \& Wahyuningtyas, N. (2018). Identifikasi Alih Fungsi Lahan Pertanian dan Kondisi Sosial Ekonomi Masyarakat Desa Karangwidoro Kecamatan Dau Kabupaten Malang. Media Komunikasi Geografi, 19(1), 114120.

Laksmiari, W. (2017). Keseimbangan Neraca Beras di Indonesia Tahun 2011-2015. Jurnal Bumi Indonesia, 6(3), 1-10.

Singgih, D. S. (2001). Pangan, Penduduk dan Teknologi Pertanian Sebuah Perdebatan Teoritis. Jurnal Masyarakat Kebudayaan Dan Politik, 14, 43-54.

Suratha, I. K. (2014). Dampak Alih Fungsi Lahan Terhadap Ketahanan Pangan. Media Komunikasi Geografi, 15(2), 52-61.
Suratha, I. K. (2015). Krisis Petani Berdampak pada Ketahanan Pangan di Indonesia. Media Komunikasi Geografi, 16(1).

Widjono. (2006). Analisis Sosial-Bidaya Pengembangan Padi di Merauke. Jurnal IPTEK Tanaman Pangan, 1(1), $1-10$. 